\title{
Clock gene dysfunction in patients with obstructive sleep apnoea syndrome
}

\author{
N. Burioka*, , S. Koyanagi ${ }^{\#, \uparrow, ~ M . ~ E n d o *, ~ M . ~ T a k a t a *, ~ Y . ~ F u k u o k a *, ~ M . ~ M i y a t a *, ~}$ \\ K. Takeda*, H. Chikumi*, S. Ohdo ${ }^{\#}$ and E. Shimizu*
}

ABSTRACT: Clock genes regulate mammalian circadian rhythms, and dysfunction of clock genes can contribute to various disorders. To investigate whether obstructive sleep apnoea syndrome (OSAS) influences clock gene function, the present authors examined Period1 (Per1) mRNA expression in vitro and in vivo.

In eight healthy subjects and eight OSAS patients, plasma noradrenaline, serum interleukin (IL)-6, high-sensitivity C-reactive protein (hsCRP) and Per1 mRNA expression in peripheral whole blood were measured. Expression of Per1 mRNA in cultured cells was examined under IL-6 or noradrenaline stimulation in vitro. After noradrenaline was administered to mice in vivo, Per1 mRNA expression in the brain was examined.

The concentrations of serum IL-6, hsCRP and plasma noradrenaline were elevated in OSAS patients, but improved by continuous positive airway pressure (CPAP) therapy. Per1 mRNA expression in the peripheral blood significantly decreased at 02:00 $\mathrm{h}$ by CPAP in OSAS patients. Stimulation with IL-6 did not directly induce Per1 mRNA in vitro. Administration of noradrenaline induced Per1 mRNA in the cerebral cortex of mice in vivo.

The current study revealed that obstructive sleep apnoea syndrome caused clock gene dysfunction, and continuous positive airway pressure helped to improve it. Sympathetic activation and elevation of the plasma noradrenaline concentration in obstructive sleep apnoea syndrome may be one of the factors involved in disorders of Period1 mRNA expression.

KEYWORDS: Clock gene, C-reactive protein, interleukin-6, noradrenaline, Period1, sleep apnoea

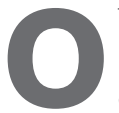
bstructive sleep apnoea syndrome (OSAS) is an important disease that contributes to excessive daytime sleepiness, mood disturbances and cardiovascular disease. Moreover, OSAS is thought to cause proinflammatory conditions, abnormal sympathetic activation and intermittent hypoxia during apnoea. A number of previous studies have examined the expression of various inflammatory factors in OSAS patients. The serum concentrations of cytokines, such as tumour necrosis factor- $\alpha$, interleukin (IL)- 6 and IL- 8 , have been reported to be elevated in OSAS patients and to be improved by continuous positive airway pressure (CPAP) therapy [1-3]. IL-6 can induce C-reactive protein $(\mathrm{CRP})$ in the mammalian liver, a process which contributes to cardiovascular disease [4]. Additionally, sympathetic activation in patients with OSAS is associated with hypertension [5].

In mammals, the circadian master clock resides in the suprachiasmatic nucleus (SCN) and entrains peripheral clock function in various tissues

For editorial comments see page 1. through neural and humoral signalling [6]. Abnormal central clock gene expression in the SCN can cause circadian sleep disorders, mood disturbances and some psychiatric diseases. Moreover, dysfunction of peripheral clock genes has been investigated in various human disorders, including tumour genesis, obesity and cardiovascular disease [7-9]. Although a detailed molecular mechanism of the circadian oscillator has been revealed in rodents that are nocturnally active, there have been few studies in diurnally active humans. Recently, human peripheral blood cells have been used for representative estimations of the mRNA expression of clock genes in other peripheral tissues [10-14].

Human (h)Period1 (Per1) is one of the important clock genes. Previous studies have shown that the Per1 promoter contains several enhancers, such as the cAMP response element (CRE) [1517] and the glucocorticoid response element (GRE) [18-20], in its 5'-upstream region. The expression of Per1 can reportedly be induced by treatment with glucocorticoids, IL- 6 and $\alpha$-adrenoceptor or $\beta$-adrenoceptor agonists [21-24]. The

\section{AFFILIATIONS}

*Division of Medical Oncology and Molecular Respirology, Faculty of Medicine, Tottori University, Yonago and

\#Pharmaceutics, Division of Clinical Pharmacy, Dept of Medico-

Pharmaceutical Sciences, Faculty of Pharmaceutical Sciences, Kyushu University, Fukuoka, Japan. "Both authors contributed equally to the study.

CORRESPONDENCE

N. Burioka

Division of Medical Oncology and Molecular Respirology

Faculty of Medicine

Tottori University

36-1 Nishimachi

Yonago 683-8504

Japan

Fax: 81859386539

E-mail: burioka@

grape.med.tottori-u.ac.jp

Received:

October 192007

Accepted after revision:

February 112008

\section{SUPPORT STATEMENT}

This study was supported by grants 17590791 and 20590923 awarded to N. Burioka from the Ministry of

Education, Culture, Sports, Science and Technology, Japan.

STATEMENT OF INTEREST

None declared. 
plasma noradrenaline and/or adrenaline and serum IL-6 concentrations are reportedly elevated in patients with OSAS [3, 25]. It has also been revealed that cortisol concentrations are elevated in severe OSAS [26]. OSAS may potentially influence hPer1 mRNA expression. However, the influence of OSAS on human clock genes has not yet been reported. In the present study, to investigate whether OSAS influences clock gene function, hPer1 mRNA expression was examined in vitro and in vivo. In humans, it is difficult to analyse the induction of clock genes in organs. Therefore, human peripheral blood cells were used to estimate the mRNA expression of clock genes.

\section{SUBJECTS AND METHODS \\ Subjects and patients}

Eight diurnally ( 06:30-23:00 h) active healthy subjects and eight patients with OSAS participated in the present study (table 1). The age and weight of the two groups were matched. The healthy subjects had no cardiovascular disease. The healthy subjects and OSAS patients generally ate breakfast between 07:00 and 08:00 $\mathrm{h}$, lunch between 12:00 and 14:00 $\mathrm{h}$ and dinner between 18:00 and 20:00 h, although they were not strictly restricted to this time schedule. No food was allowed between meals, and no caffeine-containing beverages were permitted. Local authorities (Yonago, Japan) approved the study protocol. Informed consent was obtained from all participants.

\section{Sleep studies}

All participants had undergone diagnostic polysomnography (PSG) during the night in the hospital prior to the study (at either Hitachi Memorial Hospital, Yasugi, Shimane, or Tottori University Hospital, Yonago, Japan). Signals from electroencephalograms (EEG; C3-A2 and C4-A1), electro-oculograms, submental electromyograms, ECG, arterial oxygen saturation measured by a finger pulse oximeter $\left(S_{\mathrm{p}}, \mathrm{O}_{2}\right)$, a snoring microphone, nasal and/or mouth flow using a pressure cannula, and both chest wall and abdominal efforts were recorded by PSG (SomnoTrac; SensorMedics, Yorba Linda, CA, USA). Two independent physicians each categorised the stage of consciousness on the EEG records, using the criteria of ReCHTSCHAFFEN and KALES [27]. Apnoea was defined as a cessation of air flow at the nose and / or mouth for $\geqslant 10 \mathrm{~s}$, while hypopnoea was defined as an airflow reduction of $>50 \%$ for

\begin{tabular}{|c|c|c|c|}
\hline \multirow[t]{2}{*}{ TABLE 1} & \multicolumn{3}{|c|}{$\begin{array}{l}\text { Characteristics of normal subjects and patients } \\
\text { with obstructive sleep apnoea syndrome (OSAS) }\end{array}$} \\
\hline & Normal & OSAS & $p$-value \\
\hline Sex M/F n & $7 / 1$ & $8 / 0$ & \\
\hline Age yrs & $43.1 \pm 4.8$ & $45.9 \pm 4.3$ & 0.43 \\
\hline BMI & $24.6 \pm 0.6$ & $25.9 \pm 0.6$ & 0.12 \\
\hline AHI events $\cdot h^{-1}$ & $3.8 \pm 0.6$ & $53.9 \pm 6.2$ & 0.003 \\
\hline ESS & $5.9 \pm 1.3$ & $13.6 \pm 1.2$ & 0.006 \\
\hline \multicolumn{4}{|c|}{$\begin{array}{l}\text { Data are presented as mean } \pm \mathrm{SEM} \text {, unless otherwise stated. Body mass index } \\
\text { (BMI) is defined as the weight }(\mathrm{kg}) \text { divided by the square of the height }(\mathrm{m}) \text {. The } \\
\text { Mann-Whitney U-test was used for comparisons between normal subjects and } \\
\text { patients with OSAS. M: male; F: female; AHI: apnoea/hypopnoea index; ESS: } \\
\text { Epworth sleepiness scale. }\end{array}$} \\
\hline
\end{tabular}

$\geqslant 10 \mathrm{~s}$, followed by a fall of $\geqslant 3 \%$ in the $\mathrm{Sp}_{\mathrm{p}} \mathrm{O}_{2}$ or arousal. The apnoea/hypopnoea index (AHI) was calculated as the sum of all apnoeas and hypopnoeas divided by the total sleep time, and was expressed as events $\cdot h^{-1}$. When the AHI was $>5$ events $\cdot h^{-1}$, the patient was diagnosed as having OSAS. However, only OSAS patients with an AHI $>30$ events $\cdot h^{-1}$ were included in the current study. The patients with OSAS were treated by CPAP (REMstar Auto; Respironics Japan, Tokyo, Japan) after titration. After 3 months of CPAP therapy, the patients with OSAS were also examined with PSG during the night while using CPAP. Exclusion criteria were: central apnoea syndrome; Cheyne-Stokes respiration; major facial or pharyngeal anatomic abnormalities; previous treatment with CPAP; and previous sedative or hypnotic therapy.

\section{Measurement of serum cortisol, IL-6, high-sensitivity CRP and plasma noradrenaline concentrations}

Venous blood samples of $10 \mathrm{~mL}$ were collected from eight healthy subjects and eight patients with OSAS at 18:00, 02:00, 06:00 and 14:00 h during the study day without medication. After 3 months using CPAP, 10-mL venous blood samples were also collected from the patients with OSAS at each CPAP therapy time-point. The serum and plasma samples were immediately stored at $-80^{\circ} \mathrm{C}$ until further analysis.

Serum cortisol concentrations were determined by a radioimmunoassay based on ${ }^{125}$ I-labelled cortisol (TFB Inc., Tokyo, Japan). Serum IL-6 concentrations were measured by ELISA (High-Sensitivity IL-6 Biotrak ELISA; Amersham Bioscience, Piscataway, NJ, USA). The plasma noradrenaline concentrations were measured by HPLC (catecholamine test; $\mathrm{TOSOH}$, Tokyo, Japan). The serum high-sensitivity CRP (hsCRP) concentrations were measured using a nephelometer (NLatex CRP II assay; Dade Behring, Tokyo, Japan).

\section{Per1 mRNA expression in human peripheral blood cells}

Total RNA was isolated from peripheral white blood cells in $2.5 \mathrm{~mL}$ of each whole blood sample using the PAXgene Blood RNA kit (QIAGEN, Tokyo, Japan) according to the manufacturer's instructions. The cDNA was synthesised using the QuantiTect Reverse Transcription kit (QIAGEN). Real-time PCR was performed using the LightCycler system (Roche Diagnostics, Basel, Switzerland) with the LightCycler FastStart DNA Master SYBR Green I kit (Roche Diagnostics) [16, 28]. Specific primer pairs used were as follows: h $\beta$-actin (191 bp) 5'-AGCATCCCCCAAAGTTCACA-3' and 5'-AAGCAATGCTATCACCTCCC-3'; hPer1 (132 bp) 5'-CTGAGGAGGCCGAGAGGAAAGAA-3' and 5'-AGGAGGAGGAGGCACATTTACGC-3'. The amplifications were performed using the following protocol: initial denaturation at $95^{\circ} \mathrm{C}$ for $10 \mathrm{~min}$ to activate the FastStart Taq DNA polymerase, then 45 cycles consisting of $95^{\circ} \mathrm{C}$ for $15 \mathrm{~s}, 55^{\circ} \mathrm{C}$ for $5 \mathrm{~s}$ and $72^{\circ} \mathrm{C}$ for $10 \mathrm{~s}$ (transition rates of $\left.20^{\circ} \mathrm{C} \cdot \mathrm{s}^{-1}\right)$. The fluorescence value of each capillary was measured at $530 \mathrm{~nm}$. The expression of hPer1 mRNA was determined relative to the $\mathrm{h} \beta$-actin mRNA expression.

\section{Cell culture}

Mouse embryonic fibroblast NIH3T3 cells were maintained in Dulbecco's modified Eagle medium supplemented with $10 \%$ foetal bovine serum. To determine whether IL-6 or noradrenaline induced mouse $(\mathrm{m})$ Per $1 \mathrm{mRNA}$ expression in vitro, the 


\begin{tabular}{|c|c|c|c|c|}
\hline \multirow[t]{2}{*}{ TABLE 2} & \multicolumn{4}{|c|}{$\begin{array}{l}\text { Baseline characteristics of the obstructive sleep } \\
\text { apnoea syndrome (OSAS) patients and efficacy } \\
\text { of continuous positive airway pressure (CPAP) }\end{array}$} \\
\hline & & OSAS & CPAP & $p$-value \\
\hline \multicolumn{2}{|c|}{ AHI events $\cdot h^{-1}$} & $53.9 \pm 6.2$ & $6.3 \pm 1.1$ & 0.0002 \\
\hline \multicolumn{2}{|c|}{ Arousal index events $\cdot h^{-1}$} & $51.1 \pm 6.9$ & $23.6 \pm 3.5$ & 0.0067 \\
\hline \multicolumn{2}{|c|}{ ESS } & $13.6 \pm 1.2$ & $7.9 \pm 1.1$ & 0.0094 \\
\hline \multicolumn{2}{|l|}{ TST min } & $395 \pm 27$ & $420 \pm 20$ & 0.50 \\
\hline \multicolumn{5}{|c|}{ Sleep stage \% } \\
\hline \multicolumn{2}{|c|}{ । } & $19.3 \pm 2.9$ & $14.5 \pm 1.7$ & 0.096 \\
\hline \multicolumn{2}{|l|}{$\|$} & $60.3 \pm 1.6$ & $53.3 \pm 2.2$ & 0.0045 \\
\hline \multicolumn{2}{|l|}{ III } & $2.8 \pm 1.6$ & $4.0 \pm 0.5$ & 0.478 \\
\hline \multicolumn{2}{|l|}{ IV } & $1.6 \pm 1.2$ & $6.8 \pm 1.2$ & 0.01 \\
\hline \multicolumn{2}{|l|}{ REM } & $16.1 \pm 2.1$ & $21.4 \pm 1.6$ & 0.022 \\
\hline \multicolumn{2}{|c|}{ Mean $\mathrm{Sp}, \mathrm{O}_{2}$ during sleep $\%$} & $92.3 \pm 1.1$ & $96.3 \pm 0.4$ & 0.0035 \\
\hline \multicolumn{2}{|c|}{ Min $\mathrm{Sp}, \mathrm{O}_{2}$ during sleep $\%$} & $73.6 \pm 3.4$ & $91 \pm 0.5$ & 0.0008 \\
\hline \multicolumn{2}{|c|}{$\begin{array}{l}\% \text { of TST when } \mathrm{Sp}_{\mathrm{p}, \mathrm{O}_{2}} \\
<\mathbf{9 0} \%\end{array}$} & $31.1 \pm 9.6$ & $0.8 \pm 0.4$ & 0.0145 \\
\hline \multicolumn{5}{|c|}{$\begin{array}{l}\text { Data are presented as mean } \pm \text { SEM. Paired t-tests were used to compare the } \\
\text { values before and after CPAP therapy in patients with OSAS. AHI: apnoea/ } \\
\text { hypopnoea index; ESS: Epworth sleepiness scale; TST: total sleep time; REM: } \\
\text { rapid eye movement; } S p, \mathrm{O}_{2} \text { : arterial oxygen saturation measured by pulse } \\
\text { oximetry. }\end{array}$} \\
\hline
\end{tabular}

NIH3T3 cells were treated for $24 \mathrm{~h}$ with 10,100 or $1,000 \mathrm{pg} \cdot \mathrm{mL}^{-1}$ of mouse IL-6 (R\&D Systems Inc., Minneapolis, MN, USA) or 10,25 or $50 \mathrm{ng} \cdot \mathrm{mL}^{-1}$ of noradrenaline (Sigma-Aldrich Co., St Louis, MO, USA). After treatment, the mRNA levels of mPer1 were assessed by RT-PCR.

For quantification of the relative RNA levels, the cDNAs of mPer1 and the glyceraldehyde-3-phosphate dehydrogenase $(G A P D H)$ gene were synthesised and amplified using the SuperScript ${ }^{\text {TM }}$ One-Step RT-PCR System (Invitrogen, Carlsbad, CA, USA). Specific primer pairs used were as follows: mPer1 (403 bp) 5' -CCAGGCCCGGAGAACCTTTTT-3' and 5'-CGAAGTTTGAGCTCCCGAAGTG-3'; mGAPDH (178 bp) 5'-GACCTCAACTACATGGTCTACA-3' and 5'-ACTCCACGACATACTCAGCAC-3'. To evaluate the quantitative reliability of RT-PCR, kinetic analysis of the amplified products was carried out, in order to ensure that signals were derived only from the exponential phase of amplifications. The exponential phase of GAPDH amplification in all experimental conditions occurred between the 26th and the 28th cycles, and the exponential phases of a target gene (mPer1) occurred between the 27th and the 30th cycles. The amplification efficiencies of the GAPDH and target gene were comparable. Therefore, the amplification products were collected and quantified at the 27th or 28th cycle. The ratios of the amplified target to the amplified internal control (calculated by dividing each mPer1 value by that of $G A P D H$ ) were compared between the groups.

\section{Experimental animals}

Male ICR mice aged 4-6 weeks (Tokyo Experimental Animals Co., Tokyo, Japan) were used. The animals were housed at $22 \pm 2{ }^{\circ} \mathrm{C}, 60 \pm 5 \%$ humidity, with a 12-h light/12-h dark cycle

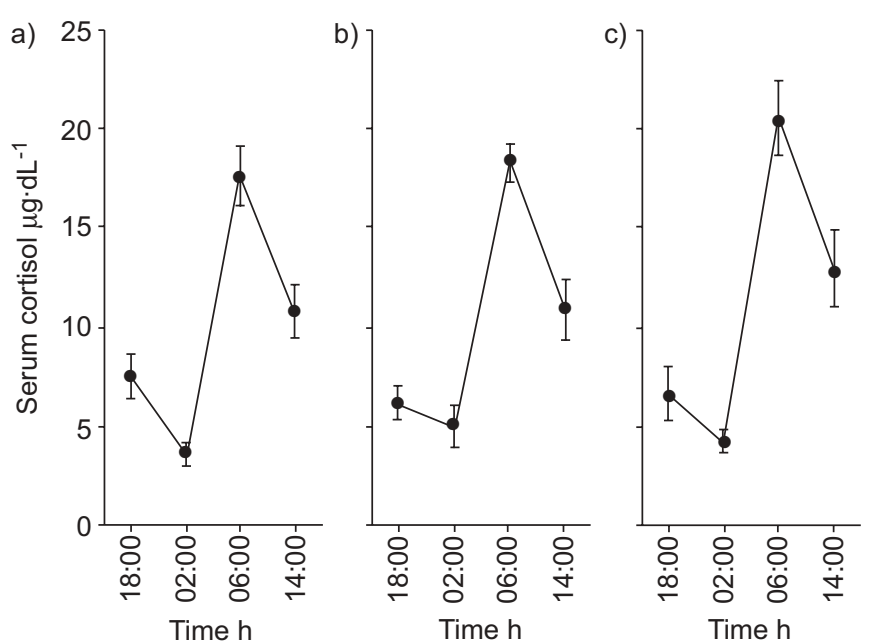

FIGURE 1. Serum cortisol concentrations in a) healthy subjects, b) patients with obstructive sleep apnoea syndrome (OSAS) and c) OSAS patients treated with continuous positive airway pressure therapy. Data are presented as mean \pm SEM, with $n=8$ in each group. The daily variations of serum cortisol concentration were found to be significant in each group using repeated-measure one-way ANOVA $(p<0.0001$ in each case). However, no statistically significant differences in the serum cortisol concentrations at each time-point were found between the three groups.

(lights on from 06:00 to 18:00 h). Zeitgeber time (ZT)0 and ZT12 were the lights-on and lights-off times, respectively. The light intensity at the surface of the cages was $\sim 100 \mathrm{~lx}$. The mice were fed a standard diet and water was available ad libitum. An osmotic miniature pump (model 2001; ALZET, Palo Alto, CA, USA) was implanted under the skin of the mice, and was used for the continuous administration of noradrenaline $\left(1.5 \mu \mathrm{g} \cdot \mathrm{h}^{-1}\right)$ or saline for 6 days.

Total RNA from mouse tissues was extracted as follows. The brain was quickly removed halfway through the light or dark phase (at ZT6 or ZT18, respectively). Coronal brain slices $(500 \mu \mathrm{m})$ were prepared using a rodent brain matrix (RBM2000C; ASI Instruments, Inc., Warren, MI, USA), and the SCN was punched out bilaterally from the brain slices. To obtain an adequate amount of RNA from the SCN, SCN material from three mice in each group was combined and extracted. The extraction of total RNA from the cerebral cortex of an individual mouse was carried out separately using the RNeasy Mini kit (QIAGEN). The mRNA levels of mPer1 were assessed by RT-PCR, as described in the previous section. Experimental animal care was conducted under permission from the Committee for Animal Experimentation in the Division of Pharmaceutical Sciences at Kyushu University (Fukuoka, Japan).

\section{Statistical analysis}

The results are presented as mean \pm SEM for all samples. The statistical differences between groups were analysed by oneway ANOVA, and multiple comparisons were performed by Fisher's protected least significant difference (PLSD) or Dunnett's test. A value of $\mathrm{p}<0.05$ was considered to indicate statistical significance. 

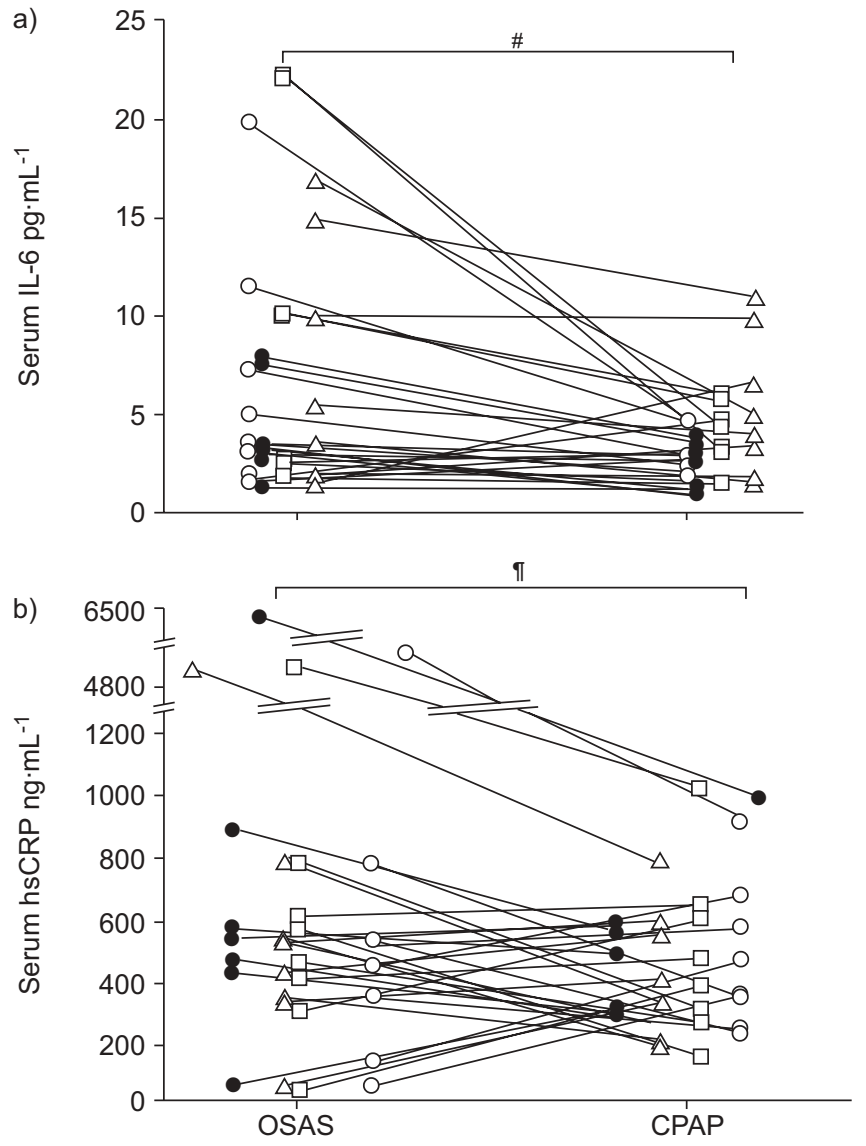

FIGURE 2. Serum interleukin (IL)-6 and high-sensitivity C-reactive protein (hSCRP) concentrations before and after continuous positive airway pressure (CPAP) therapy in patients with obstructive sleep apnoea syndrome (OSAS). a) The serum IL-6 concentration was significantly decreased by CPAP therapy in patients with OSAS. b) The serum hsCRP concentration was also significantly decreased by CPAP therapy in patients with OSAS. Paired t-tests were used to compare the values before and after CPAP therapy in patients with OSAS. Values were measured

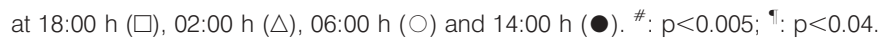

\section{RESULTS}

\section{Efficacy of CPAP therapy}

After using CPAP for 3 months, a repeat night-time PSG was performed in patients with OSAS. The AHI and Epworth sleepiness scale index were significantly decreased and improved by CPAP. The other indices were also clearly improved by CPAP therapy (table 2). The CPAP device can record usage automatically, and the compliance of CPAP therapy was objectively calculated. The mean \pm SEM time of CPAP use was $5.2 \pm 0.4 \mathrm{~h} \cdot$ night $^{-1}$. The average proportion of CPAP use was $75 \pm 3.6 \%$, calculated by dividing the number of days when patients used the CPAP device by the total number of days of the study.

\section{Serum cortisol concentration}

Figure 1 shows the daily variations of serum cortisol concentrations in healthy subjects, patients with OSAS, and OSAS patients treated with CPAP therapy for 3 months. In each group, the serum concentrations of cortisol were significantly lowest at 02:00 $\mathrm{h}$ and consistently highest at 06:00 $\mathrm{h}$, using

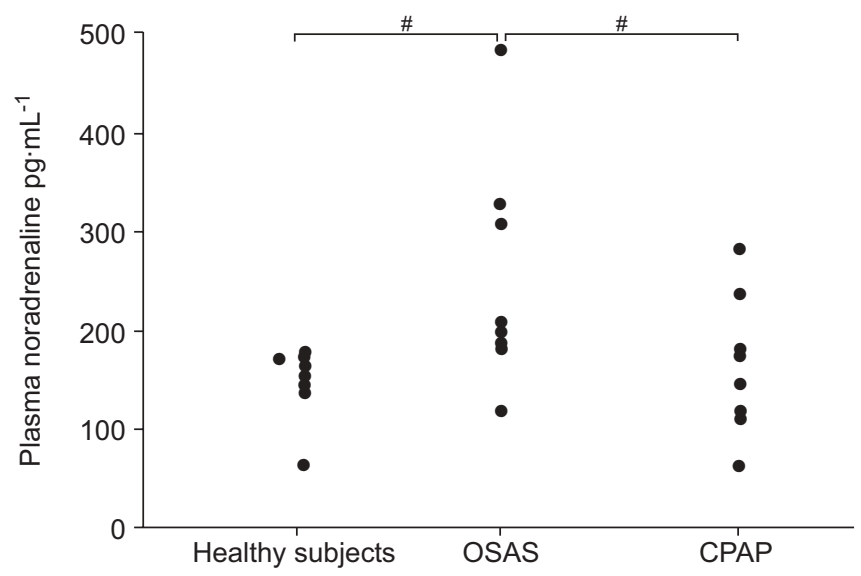

FIGURE 3. Plasma noradrenaline concentration at 02:00 $\mathrm{h}$ in healthy subjects patients with obstructive sleep apnoea syndrome (OSAS) and OSAS treated with continuous positive airway pressure (CPAP). The variation in the plasma noradrenaline concentrations in the supine position between the three groups was significant by one-way ANOVA. The plasma noradrenaline concentration in the OSAS patients was significantly higher than that in the healthy subjects, and CPAP therapy significantly decreased the plasma noradrenaline concentration, as measured by Fisher's protected least significant difference. ${ }^{*}: p<0.04$.

Fisher's PLSD test. No statistically significant differences in the serum cortisol concentrations at each time-point were found between the three groups. The $24-\mathrm{h}$ mean \pm SEM serum cortisol levels were $9.9 \pm 1.7 \mu \mathrm{g} \cdot \mathrm{dL}^{-1}$ in the normal subjects, $10.1 \pm 1.8 \mu \mathrm{g} \cdot \mathrm{dL}^{-1}$ in the OSAS patients and $11.4 \pm 2.0 \mu \mathrm{g} \cdot \mathrm{dL}^{-1}$ in the OSAS patients treated with CPAP. No statistically significant differences in the $24-h$ mean serum cortisol concentrations were found. Individually, all subjects showed normal daily variation and phasing of cortisol secretion.

\section{Serum IL-6 and hsCRP}

The mean \pm SEM serum IL-6 concentrations in the healthy subjects were $1.6 \pm 0.1,1.5 \pm 0.2,1.7 \pm 0.3$ and $1.6 \pm 0.2 \mathrm{pg} \cdot \mathrm{mL}^{-1}$ at 18:00, 02:00, 06:00 and 14:00 $\mathrm{h}$, respectively. In the patients with OSAS, the serum IL-6 concentrations at the same timepoints were $9.1 \pm 2.7,7.0 \pm 1.8,6.6 \pm 1.9$ and $4.0 \pm 0.7 \mathrm{pg} \cdot \mathrm{mL}^{-1}$. After CPAP therapy for 3 months, the serum IL-6 concentrations in the OSAS patients were $3.8 \pm 0.5,5.4 \pm 1.0,2.8 \pm 0.4$ and $2.4 \pm 0.3 \mathrm{pg} \cdot \mathrm{mL}^{-1}$ at 18:00, 02:00, 06:00 and 14:00 $\mathrm{h}$, respectively. The 24-h mean serum concentrations of IL-6 were $1.6 \pm 0.3 \mathrm{pg} \cdot \mathrm{mL}^{-1}$ in the healthy subjects, $6.7 \pm 1.2 \mathrm{pg} \cdot \mathrm{mL}^{-1}$ in the patients with OSAS and $3.6 \pm 0.6 \mathrm{pg} \cdot \mathrm{mL}^{-1}$ in the OSAS patients treated with CPAP. A significant difference was found between the three groups by one-way ANOVA $(p<0.05)$. The serum concentrations of IL- 6 were significantly decreased by CPAP therapy $(p<0.005$; fig. $2 a)$.

The mean \pm SEM serum hsCRP concentrations in the healthy subjects were $255 \pm 63,237 \pm 61,188 \pm 40$ and $245 \pm 59 \mathrm{ng} \cdot \mathrm{mL}^{-1}$ at 18:00, 02:00, 06:00 and 14:00 $\mathrm{h}$, respectively. In the patients with OSAS, the serum hsCRP concentrations at the same timepoints were $1,011 \pm 475,985 \pm 479, \quad 1,008 \pm 522$ and $1,240 \pm 636 \mathrm{ng} \cdot \mathrm{mL}^{-1}$. After CPAP therapy for 3 months, the serum hsCRP concentrations in the OSAS patients were $487 \pm 82,424 \pm 62,473 \pm 70$ and $475 \pm 73 \mathrm{ng} \cdot \mathrm{mL}^{-1}$ at 18:00, 02:00, 06:00 and 14:00 $\mathrm{h}$, respectively. The 24-h mean serum 

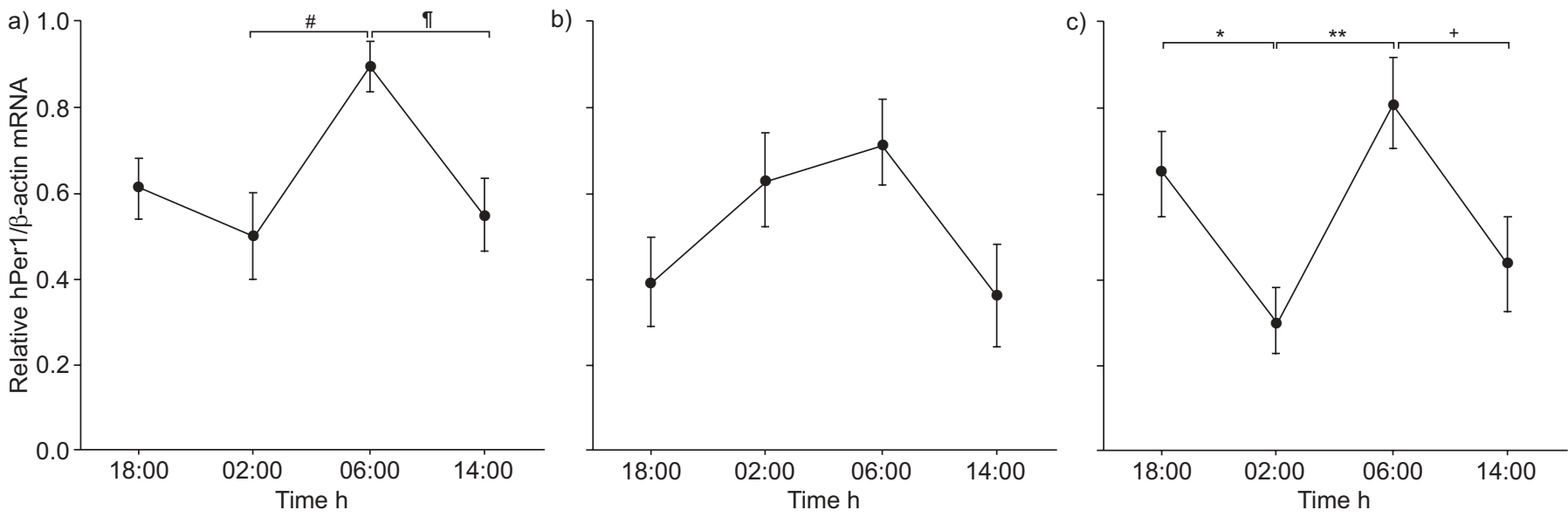

FIGURE 4. Variation in the relative values of human Period1 (hPer1) mRNA expression in human peripheral blood cells, as determined by real-time PCR analysis in a) healthy subjects, b) patients with obstructive sleep apnoea syndrome (OSAS) and c) OSAS patients treated with continuous positive airway pressure (CPAP) therapy. Data are presented as mean \pm SEM, with $\mathrm{n}=8$ in each group. The value for $\mathrm{hPe} 1 \mathrm{mRNA}$ expression at each time-point was divided by each peak value. The expression of $\mathrm{hPer1}$ mRNA was determined relative to the $\beta$-actin mRNA expression. The variation in the relative values of hPer1 mRNA expression at four time-points was statistically significant in the healthy subjects and in the patients with OSAS during CPAP therapy, by repeated-measure one-way ANOVA. Multiple comparisons were performed by Fisher's protected least significant difference. ${ }^{*}: p<0.02 ;{ }^{\bullet}: p<0.03 ;^{+}: p<0.04 ;^{*}: p<0.05 ;{ }^{* *}: p<0.01$.

concentrations of hsCRP were $231 \pm 41 \mathrm{ng} \cdot \mathrm{mL}^{-1}$ in the healthy subjects, $1,061 \pm 188 \mathrm{ng} \cdot \mathrm{mL}^{-1}$ in the patients with OSAS and $465 \pm 82 \mathrm{ng} \cdot \mathrm{mL}^{-1}$ in the OSAS patients treated with CPAP. A significant difference was found between the three groups by one-way ANOVA $(\mathrm{p}<0.05)$. The serum concentration of hsCRP was significantly decreased by CPAP therapy ( $<<0.04$; fig. $2 b$ ).

\section{Levels of plasma noradrenaline}

The plasma noradrenaline concentrations in the supine position at $02: 00 \mathrm{~h}$ were $144 \pm 11 \mathrm{pg} \cdot \mathrm{mL}^{-1}$ in the healthy subjects, $251 \pm 35 \mathrm{pg} \cdot \mathrm{mL}^{-1}$ in the patients with OSAS and $158 \pm 22 \mathrm{pg} \cdot \mathrm{mL}^{-1}$ in the OSAS patients treated with CPAP. The plasma noradrenaline concentrations were significantly different between the three groups by one-way ANOVA $(p<0.05)$, and significantly decreased after CPAP therapy (Fisher's PLSD; $\mathrm{p}<0.04$; fig. 3).

\section{Per1 mRNA expression in peripheral whole blood cells by real-time PCR analysis}

Figure 4 shows the hPer1 mRNA expression in peripheral whole blood cells according to real-time PCR analysis. The value for hPer1 mRNA expression at each time-point was divided by each peak value. Significant daily variations of hPer1 mRNA expression in peripheral whole blood cells from the healthy subjects and OSAS patients treated with CPAP were found by repeated-measure one-way ANOVA $(\mathrm{p}<0.05$ and $\mathrm{p}<0.03$, respectively). However, no significant daily variation of hPer1 mRNA expression was found in OSAS patients. It was confirmed that hPer1 mRNA expression in healthy subjects at $06: 00 \mathrm{~h}$ was significantly higher than at 02:00 h or at 14:00 h, by multiple comparisons using Fisher's PLSD ( $\mathrm{p}<0.02$ and $\mathrm{p}<0.03$, respectively; fig. $4 a)$. The highest $\mathrm{hPer1}$ transcription in peripheral blood was previously observed in healthy human subjects at times experienced as morning $[10,11,13,14]$. The current result was consistent with these previous reports.
In particular, the relative values at $02: 00 \mathrm{~h}$ were significantly different between the three groups $(p<0.04$; one-way ANOVA). In the OSAS patients treated with CPAP, the relative value for $\mathrm{hPer} 1 \mathrm{mRNA}$ expression at $02: 00 \mathrm{~h}$ was significantly lower than at 02:00 $\mathrm{h}$ in the OSAS patients before treatment, as determined by Fisher's PLSD $(\mathrm{p}<0.02)$. CPAP therapy significantly improved the alteration in hPer1 mRNA expression in the OSAS patients.

\section{Per1 mRNA expression in NIH3T3 cells by stimulating with IL-6 and noradrenaline in vitro}

Treatment of NIH3T3 cells with IL-6 resulted in no significant induction of mPer1 mRNA by one-way ANOVA, although a high concentration $\left(1,000 \mathrm{pg} \cdot \mathrm{mL}^{-1}\right)$ of IL- 6 slightly induced mPer1 mRNA (fig. 5a). Conversely, treatment of NIH3T3 cells with noradrenaline caused an induction of mPer1 mRNA in a concentration-dependent manner (one-way ANOVA; $\mathrm{p}<0.003$; fig. 5b). Significant inductions of mPer1 mRNA were observed using Dunnett's test when the cells were treated with 25 and $50 \mathrm{ng} \cdot \mathrm{mL}^{-1}$ noradrenaline $(\mathrm{p}<0.05$ in each case; fig. 5b).

\section{Per1 mRNA expression in the mouse brain during the administration of noradrenaline in vivo}

Male ICR mice were exposed for 3 weeks to a 12-h light/12-h dark cycle. Following this, noradrenaline was administered continuously to three mice via an osmotic pump for 6 days. In the SCN, mPer1 mRNA was not induced by noradrenaline during either the light (ZT6) or dark (ZT18) periods. However, mPer1 mRNA was significantly induced in the cerebral cortex during the light period when the mouse was asleep and not active $(p<0.05$; fig. 6$)$. Briefly, mPer1 mRNA in the central biological clock was not influenced by noradrenaline, but mPer1 mRNA expression was induced in the peripheral tissues. 


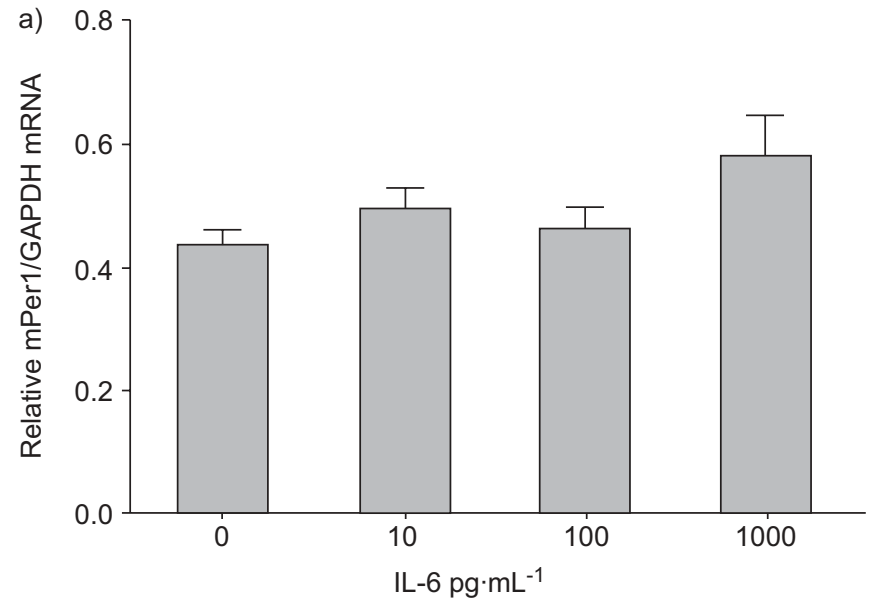

b)

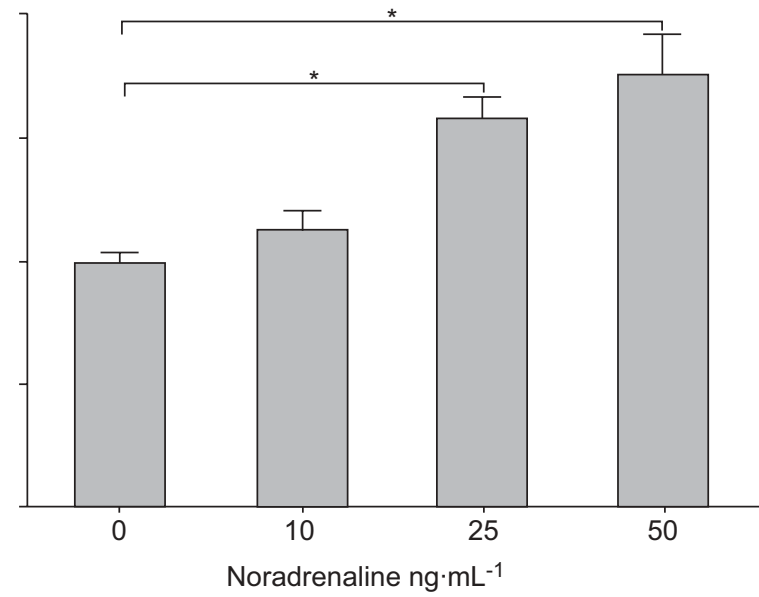

FIGURE 5. Mouse Period1 (mPer1) mRNA expression in mouse NIH3T3 cells by stimulating with a) interleukin (IL)-6 or b) noradrenaline in vitro. The expression of mPer1 mRNA was determined relative to glyceraldehyde-3-phosphate dehydrogenase (GAPDH) mRNA expression using RT-PCR analysis. Data are presented as mean \pm sEM, with $\mathrm{n}=3$ for each concentration. Treatment of NIH3T3 cells with IL-6 resulted in no significant induction of mPer1 mRNA. Conversely, treatment of NIH3T3 cells with noradrenaline caused a significant induction of mPer1 mRNA in a concentration-dependent manner, as determined by one-way ANOVA. Significant inductions of mPer1 mRNA were observed using Dunnett's test when the cells were treated with 25 and $50 \mathrm{ng} \cdot \mathrm{mL}^{-1}$ noradrenaline. ${ }^{*}: \mathrm{p}<0.05$.

\section{DISCUSSION}

The current study revealed that the daily variation of hPer1 mRNA expression in the peripheral whole blood cells from OSAS patients was different from that in healthy subjects. In the OSAS patients, no significant daily variation of hPer1 mRNA expression in the peripheral whole blood cells was found. CPAP therapy significantly improved the alteration in hPer1 mRNA expression in the OSAS patients. The factors that influenced Per 1 mRNA expression were examined. Treatment of NIH3T3 cells with noradrenaline induced mPer1 mRNA in a concentration-dependent manner in vitro. Moreover, the administration of noradrenaline induced mPer1 mRNA in the cerebral cortex of mice in vivo. However, prolonged stimulation with IL-6 did not induce mPer1 expression in vitro.
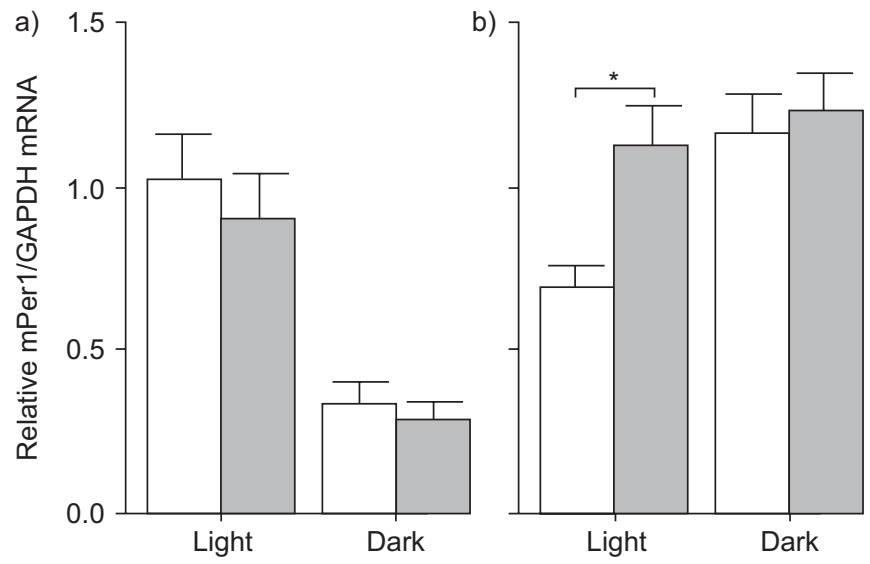

FIGURE 6. Mouse Period1 (mPer1) mRNA expression in the mouse brain during administration of noradrenaline in vivo. Noradrenaline was administered continuously to three mice by osmotic pump for 6 days. Data are presented as mean \pm SEM. a) In the suprachiasmatic nucleus, mPer1 mRNA was not induced by noradrenaline $(\square)$ during either the light or dark periods, compared with control saline administration ( $\square$ ). b) In the cerebral cortex, mPer1 mRNA was significantly induced by noradrenaline during the light period. *: $p<0.05$.
Sympathetic activation in OSAS patients may be one of the factors involved in the dysfunction of Per1 mRNA expression during sleep. In addition, CPAP was useful for improving the serum CRP, IL-6 and plasma noradrenaline concentrations, and dysfunction of the clock gene, hPer1. Per1 mRNA expression in the peripheral blood cells may be a new index for evaluating the efficacy of CPAP therapy in OSAS patients.

\section{Glucocorticoid signals to the mammalian clock gene Per1}

Previous reports have shown that circadian expression of Per1 can be elicited by multiple signalling factors, such as: epidermal growth factor, equine serum in high concentration, forskolin, phorbol ester, glucocorticoids and sympathetic neuron-related factors $[6,15]$. Glucocorticoid is a particularly potent signal that elicits rhythmic mRNA expression in peripheral clock genes. Several reports have suggested that the increase in Per1 mRNA accumulation is caused by glucocorticoid signalling via the GRE consensus sequences in Per1 [18-20]. Rat Per1 mRNA expression in cultured rat-1 fibroblasts was reportedly induced by a glucocorticoid hormone analogue, dexamethasone [21]. It has also been previously confirmed that stimulation with dexamethasone strongly induced hPer1 mRNA in cultured human bronchial epithelial cells, BEAS-2B [22]. Moreover, it has been reported that injection of prednisolone in vivo markedly induced hPer1 mRNA expression in human peripheral blood mononuclear cells after $1 \mathrm{~h}$ [28].

One study has reported that cortisol concentrations were elevated in severe OSAS [26]. However, another reported that OSAS was not associated with any change in the level of salivary or plasma cortisol rhythmicity [29]. In the present study, since no statistically significant differences in the serum cortisol concentrations at each time-point were found between healthy subjects, severe OSAS patients and severe OSAS patients treated with CPAP, the mechanism of induction of $\mathrm{h}$ Per1 mRNA at 02:00 $\mathrm{h}$ in OSAS patients may not be related to the signalling pathway via GRE. 


\section{Effect of stimulation of IL-6 on Per1 mRNA expression}

In the present study, the serum concentrations of both IL-6 and hsCRP in OSAS patients were significantly higher than those in healthy subjects and were found to be decreased by CPAP. It has been reported that hypoxia can activate various transcriptional factors of nuclear factor (NF)- $\kappa B$ and NF-IL-6, and can increase the production of IL-6 [30]. IL-6 is an important proinflammatory cytokine that has been implicated in the pathogenesis of atherosclerosis. Plasma concentrations of IL-6 are reportedly correlated with the mortality rate in patients with unstable coronary artery disease and with the risk of myocardial infarction [31]. Serum CRP concentrations are elevated in patients with OSAS [3], because IL-6 induces the synthesis of all acute-phase proteins, including CRP [4].

A previous report has suggested that stimulation with a high concentration of IL- 6 could induce hPer 1 mRNA in cultured cells [23]. To investigate whether IL-6 could directly induce Per1 mRNA in vitro, cultured NIH3T3 cells were stimulated with IL-6 for $24 \mathrm{~h}$. Treatment of NIH3T3 cells with IL-6 resulted in no significant induction of $\mathrm{mPer} 1 \mathrm{mRNA}$, although a high concentration $\left(1,000 \mathrm{pg} \cdot \mathrm{mL}^{-1}\right)$ of IL- 6 slightly induced mPer1 mRNA. The current authors postulated that IL-6 elevation might not directly induce hPer1 mRNA.

\section{Effect of noradrenaline on induction of Per1 mRNA}

OSAS causes an increase in sympathetic activity [25]. Urinary excretion of noradrenaline and/or adrenaline in OSAS patients is higher than in normal subjects [32]. The elevated circulating noradrenaline concentrations or elevated urinary noradrenaline excretion are considered to be markers of severity of OSAS [33]. The present study found that the plasma noradrenaline concentration increased in patients with OSAS.

Adrenoceptor agonists can reportedly induce the expression of Per1 by the CAMP-protein kinase A-CRE-binding protein or mitogen-activated protein kinase-CRE-binding protein signal pathways [16, 24, 34]. The current authors examined whether noradrenaline could induce Per1 mRNA in vitro and in vivo. Treatment of NIH3T3 cells with noradrenaline caused an induction of mPer1 mRNA in a concentration-dependent manner. In addition, noradrenaline was administered to three mice by osmotic pump for 6 days in vivo. In the SCN, mPer1 mRNA was not induced by noradrenaline during either the light or dark periods, but mPer1 mRNA was significantly induced in the cerebral cortex during the light period when the mice were not active. Thus, it was confirmed that stimulation with noradrenaline induced Per1 mRNA expression in vitro and in vivo. However, since it is still unclear whether the induction of Per1 mRNA in the cerebral cortex may have an influence on emotion, additional research is needed to clarify its actual physiological impacts.

OSAS causes intermittent hypoxia, which activates hypoxiainducible factor (HIF)-1-mediated transcription. The transcriptional activator HIF-1 is regarded as a master regulator of oxygen homeostasis during hypoxia that regulates the expression of many genes [35]. Moreover, RYAN et al. [36] recently indicated that intermittent hypoxia activated the NF- $\kappa B$ inflammatory pathway and might be associated with a specific role in the pathophysiology of cardiovascular complications in OSAS. Further studies will be needed to investigate whether intermittent hypoxia can induce hPer1 mRNA in vitro and in vivo.

In conclusion, sympathetic activation and elevation of plasma noradrenaline may be one of the factors that increase Period1 mRNA expression during sleep in patients with obstructive sleep apnoea syndrome. Continuous positive airway pressure therapy is useful for improving the abnormal changes in the serum interleukin-6, C-reactive protein and plasma noradrenaline concentrations, and human Period1 mRNA expression in patients with obstructive sleep apnoea syndrome. In addition, peripheral blood cells provide an easier way to evaluate changes in the expression of peripheral clock genes. Human peripheral blood cells may be used to make representative estimations of clock gene mRNA expression. However, the actual physiological impacts are still unclear, and further studies will be needed to determine the relationship between the dysfunction of the clock gene in obstructive sleep apnoea syndrome patients and clinical symptoms, such as excessive daytime sleepiness and mood disturbances.

\section{REFERENCES}

1 Ohga E, Tomita T, Wada $H$, Yamamoto $H$, Nagase $T$, Ouchi Y. Effects of obstructive sleep apnea on circulating ICAM-1, IL-8, and MCP-1. J Appl Physiol 2003; 94: 179-184.

2 Ryan S, Taylor CT, McNicholas WT. Predictors of elevated nuclear factor-кB-dependent genes in obstructive sleep apnea syndrome. Am J Respir Crit Care Med 2006; 174: 824-830.

3 Yokoe T, Minoguchi K, Matsuo H, et al. Elevated levels of C-reactive protein and interleukin-6 in patients with obstructive sleep apnea syndrome are decreased by nasal continuous positive airway pressure. Circulation 2003; 107: 1129-1134.

4 Mortensen RF. C-reactive protein, inflammation, and innate immunity. Immunol Res 2001; 24: 163-176.

5 Coughlin SR, Mawdsley L, Mugarza JA, Wilding JP, Calverley PM. Cardiovascular and metabolic effects of CPAP in obese males with OSA. Eur Respir J 2007; 29: 720-727.

6 Schibler U, Ripperger J, Brown SA. Peripheral circadian oscillators in mammals: time and food. J Biol Rhythms 2003; 18: $250-260$

$7 \mathrm{Fu} \mathrm{L}$, Lee CC. The circadian clock: pacemaker and tumour suppressor. Nat Rev Cancer 2003; 3: 350-361.

8 Shimba S, Ishii N, Ohta Y, et al. Brain and muscle Arnt-like protein-1 (BMAL1), a component of the molecular clock, regulates adipogenesis. Proc Natl Acad Sci USA 2005; 102: 12071-12076.

9 Young ME. The circadian clock within the heart: potential influence on myocardial gene expression, metabolism, and function. Am J Physiol Heart Circ Physiol 2006; 290: H1-H16.

10 Boivin DB, James FO, Wu A, Cho-Park PF, Xiong $\mathrm{H}$, Sun ZS. Circadian clock genes oscillate in human peripheral blood mononuclear cells. Blood 2003; 102: 4143-4145.

11 Kusanagi H, Mishima K, Satoh K, Echizenya M, Katoh T, Shimizu T. Similar profiles in human period1 gene expression in peripheral mononuclear and polymorphonuclear cells. Neurosci Lett 2004; 365: 124-127.

12 Takata M, Burioka N, Ohdo S, et al. Daily expression of mRNAs for the mammalian Clock genes Per2 and Clock in mouse suprachiasmatic nuclei and liver and human 
peripheral blood mononuclear cells. Jpn J Pharmacol 2002; 90: 263-269.

13 Burioka N, Takata M, Endo M, et al. Treatment with $\beta_{2^{-}}$ adrenoceptor agonist in vivo induces human clock gene, Per1, mRNA expression in peripheral blood. Chronobiol Int 2007; 24: 183-189.

14 Takimoto M, Hamada A, Tomoda A, et al. Daily expression of clock genes in whole blood cells in healthy subjects and a patient with circadian rhythm sleep disorder. Am J Physiol Regul Integr Comp Physiol 2005; 289: R1273-R1279.

15 Burioka N, Fukuoka Y, Takata M, et al. Circadian rhythms in the CNS and peripheral clock disorders: function of clock genes: influence of medication for bronchial asthma on circadian gene. J Pharmacol Sci 2007; 103: 144-149.

16 Takata $M$, Burioka N, Ohdo $S$, et al. $\beta_{2}$-Adrenoceptor agonists induce the mammalian clock gene, hPer1, mRNA in cultured human bronchial epithelium cells in vitro. Chronobiol Int 2005; 22: 777-783.

17 Travnickova-Bendova Z, Cermakian N, Reppert SM, Sassone-Corsi P. Bimodal regulation of mPeriod promoters by CREB-dependent signaling and CLOCK/BMAL1 activity. Proc Natl Acad Sci USA 2002; 99: 7728-7733.

18 Hida A, Koike N, Hirose M, Hattori M, Sakaki Y, Tei H. The human and mouse Period1 genes: five well-conserved E-boxes additively contribute to the enhancement of mPer1 transcription. Genomics 2000; 65: 224-233.

19 Koyanagi S, Okazawa S, Kuramoto Y, et al. Chronic treatment with prednisolone represses the circadian oscillation of clock gene expression in mouse peripheral tissues. $\mathrm{Mol}$ Endocrinol 2006; 20: 573-583.

20 Le Minh N, Damiola F, Tronche F, Schütz G, Schibler U. Glucocorticoid hormones inhibit food-induced phaseshifting of peripheral circadian oscillators. EMBO J 2001; 20: 7128-7136.

21 Balsalobre A, Brown SA, Marcacci L, et al. Resetting of circadian time in peripheral tissues by glucocorticoid signaling. Science 2000; 289: 2344-2347.

22 Burioka N, Takata M, Okano Y, et al. Dexamethasone influences human clock gene expression in bronchial epithelium and peripheral blood mononuclear cells in vitro. Chronobiol Int 2005; 22: 585-590.

23 Motzkus D, Albrecht U, Maronde E. The human PER1 gene is inducible by interleukin-6. J Mol Neurosci 2002; 18: 105-109.

24 Terazono H, Mutoh T, Yamaguchi S, et al. Adrenergic regulation of clock gene expression in mouse liver. Proc Natl Acad Sci USA 2003; 100: 6795-6800.
25 Coy TV, Dimsdale JE, Ancoli-Israel S, Clausen J. Sleep apnoea and sympathetic nervous system activity: a review. J Sleep Res 1996; 5: 42-50.

26 Parlapiano C, Borgia MC, Minni A, Alessandri N, Basal I, Saponara M. Cortisol circadian rhythm and 24-hour Holter arterial pressure in OSAS patients. Endocr Res 2005; 31: 371-374.

27 Rechtschaffen A, Kales A. A Manual of Standardized Terminology, Techniques and Scoring System for Sleep Stages of Human Subjects. Los Angeles, University of California at Los Angeles Brain Information Service/Brain Research Institute, 1968.

28 Fukuoka Y, Burioka N, Takata M, et al. Glucocorticoid administration increases hPer1 mRNA levels in human peripheral blood mononuclear cells in vitro or in vivo. J Biol Rhythms 2005; 20: 550-553.

29 Dadoun F, Darmon P, Achard V, et al. Effect of sleep apnea syndrome on the circadian profile of cortisol in obese men. Am J Physiol Endocrinol Metab 2007; 293: E466-E474.

30 Matsui H, Ihara Y, Fujio Y, et al. Induction of interleukin (IL) 6 by hypoxia is mediated by nuclear factor (NF)- $\kappa \mathrm{B}$ and NF-IL-6 in cardiac myocytes. Cardiovasc Res 1999; 42: 104-112.

31 Ridker PM, Rifai N, Stampfer MJ, Hennekens CH. Plasma concentration of interleukin-6 and the risk of future myocardial infarction among apparently healthy men. Circulation 2000; 101: 1767-1772.

32 Marrone O, Riccobono L, Salvaggio A, Mirabella A, Bonanno A, Bonsignore MR. Catecholamines and blood pressure in obstructive sleep apnea syndrome. Chest 1993; 103: 722-727.

33 Ziegler MG, Mills PJ, Loredo JS, Ancoli-Israel S, Dimsdale JE. Effect of continuous positive airway pressure and placebo treatment on sympathetic nervous activity in patients with obstructive sleep apnea. Chest 2001; 120: 887-893.

34 Akiyama M, Minami Y, Kuriyama K, Shibata S. MAP kinase-dependent induction of clock gene expression by $\alpha_{1^{-}}$ adrenergic receptor activation. FEBS Lett 2003; 542: 109-114.

35 Manalo DJ, Rowan A, Lavoie $\mathrm{T}$, et al. Transcriptional regulation of vascular endothelial cell responses to hypoxia by HIF-1. Blood 2005; 105: 659-669.

36 Ryan S, Taylor CT, McNicholas WT. Selective activation of inflammatory pathways by intermittent hypoxia in obstructive sleep apnea syndrome. Circulation 2005; 112: 2660-2667. 